\title{
Mitigation of bark stripping on spruce: the need for red deer population control
}

\author{
Romain Candaele $^{1}\left(\mathbb{D} \cdot\right.$ Philippe Lejeune $^{1} \cdot$ Alain Licoppe $^{2}$ (1) $\cdot$ Céline Malengreaux $^{2} \cdot$ Yves Brostaux $^{1}$. \\ Kevin Morelle ${ }^{3}$ (D) Nicolas Latte ${ }^{1}$ (1)
}

Received: 14 November 2019 / Revised: 1 October 2020 / Accepted: 7 October 2020

○) Springer-Verlag GmbH Germany, part of Springer Nature 2020

\begin{abstract}
Norway spruce (Picea abies (L.) Karst.) is a major production tree species for the European wood industry. However, it is highly sensitive to bark stripping (BS) by red deer (Cervus elaphus L.), which causes large timber losses. Because the red deer population has increased over the last decades, a better understanding of the underlying causes driving BS is urgently needed. BS outbreaks are multifactorial: winter food shortage, local and regional deer abundance and stand properties (thermal and visual cover, and scarcity of herbaceous layers) have been found to drive BS rates. Although the influence of each of these factors is well studied, there is still no consensus on their relative contributions to BS or what mitigation strategy is best. In this study, we made use of a long-term, large-scale BS inventory (13 years over $2570 \mathrm{~km}^{2}$ ) to fill these gaps. We modeled winter and summer BS rates in response to the most explanatory variables, selected from a large set of environmental variables. Our results highlight the prevalence of deer abundance combined with high sensitivity of coniferous thickets and pronounced habitat selection by deer for these stands. Our findings show that the control of red deer populations is a key measure for reducing BS in Norway spruce stands.
\end{abstract}

Keywords Cervus elaphus $\cdot$ Picea abies $\cdot$ Coniferous stands $\cdot$ Damage prevention $\cdot$ Wallonia $\cdot$ Generalized additive models

\section{Introduction}

Coniferous forest production accounts for more than half of the world's industrial roundwood and $70 \%$ of its sawnwood. European forests are the biggest industrial roundwood producers (FAO. 2020), and 70\% of this production comes from conifer forests comprising half of the total forest area on the continent (Timbal et al. 2005).

Norway spruce (Picea abies (L.) Karst.) and Douglas fir (Pseudotsuga mensiesii (Mirb.) Franco) are species of prime

Communicated by Gediminas Brazaitis.

Romain Candaele

romain.candaele@gmail.com

1 Gembloux Agro-Bio Tech (ULiège), TERRA - Forest Is Life, Gembloux, Belgium

2 Département de L'Etude du Milieu Naturel Et Agricole, Service Public de Wallonie, Gembloux, Belgium

3 Department of Game Management and Wildlife Biology, Faculty of Forestry and Wood Sciences, Czech University of Life Sciences, Prague, Czech Republic importance for European wood production. Norway spruce is the prime species in boreal and subalpine regions and became an important production species outside its natural distribution area during the nineteenth century, especially in North Atlantic, Central European and Mediterranean mountain areas, where its productivity is especially high (Timbal et al. 2005; EUFORGEN 2013; Caudullo et al. 2016). Douglas fir was introduced in Europe from North America in the end of the nineteenth century. This species comprises only $0.4 \%$ of the European forest areas, but this proportion is growing constantly. It is increasingly favored essentially in sub-Atlantic regions (Spiecker et al. 2019) where its much higher productivity has led forest managers to partly replace spruce by Douglas fir. The highest proportions of Douglas fir are found in the Benelux countries $(<3 \%$, Spiecker et al. 2019).

An overall decline of spruce is expected in Europe and has already started in some countries, such as Germany (Timbal et al. 2005). This decline is pronounced in Wallonia (Southern Belgium), where 13\% of coniferous areas were abandoned between 1984 and 2008 and harvests have reached $143 \%$ of growth at the beginning of the 21th century 
(Alderweireld et al. 2015). Climate change and ungulate damage are aggravating threats that cause substantial production losses and deter forest owners from investing in spruce plantations. At the same time, demand for roundwood and sawnwood is still growing worldwide (FAO. 2020) and in Wallonia, especially for coniferous wood. Without precautionary measures, the wood industry could face a break in the supply chain.

Norway spruce is among those species most sensitive to bark stripping (BS), i.e., the gnawing and eating of the bark of young forest stands by ungulates (Fehér et al. 2016). BS results in extensive losses in quality and quantity of wood production. Wood decay (Burnevča et al. 2016), due to fungal infection, spreads vertically along the tree and increases stand sensitivity to wind and snow damage (Burnevča et al. 2016; Čermák et al. 2004; Čermák and Strejček 2007; Vasiliauskas et al. 1996). A recent study has also evidenced significantly decreased productivity and increased sensitivity of stripped Norway spruces to drought and heatwaves (Cukor et al. 2019). The probability of wood decay is proportional to wound size (Vasaitis et al. 2012) and site fertility (Vasaitis et al. 2012; Burnevča et al. 2016).

On average, a Norway spruce loses $35 \%$ of its standing value when its bark has been stripped (Vasiliauskas 2001; Heyninck 2014). Wood decay is present in $68 \%$ of stripped spruce, resulting in a loss of $42 \%$ of merchantable timber volume. In Wallonia (Southern Belgium), Norway spruce is the main timber production species (35\% of the productive areas and $43 \%$ of standing volume) and also the species the most affected by BS. Norway spruce accounts for $97 \%$ of the 6 million cubic meters damaged in Wallonia (Alderweireld et al. 2015).

In Europe, the red deer (Cervus elaphus) is the most frequently mentioned species feeding on spruce bark, although fallow deer (Dama dama) (Gill 1992), moose (Alces alces) (Månsson and Jarnemo 2013) and sika deer (C. nippon) (Ueda et al. 2002; Ando et al. 2003; Honda et al. 2008) also strip trees. The red deer population has dramatically increased in the last few decades in Wallonia (Bertouille et al. 2015) and in many other regions of Europe (Milner et al. 2006; Apollonio et al. 2010).

Identifying the main drivers of BS is challenging because they depend on numerous factors that change spatially and over time. Potential causes of BS are many and still partly understood (Saint-Andrieux et al. 2009). Winter climate conditions, food shortage under snow conditions, forest characteristics, anthropogenic features and landform have been shown to have influence (Gill 1992; Ueda et al. 2002; Akashi and Terazawa 2005; Verheyden et al. 2006; Vospernik 2006; Kiffner et al. 2008; Månsson et al. 2012; Fehér et al. 2016). Table 1 shows the inventory data and factors identified in the recent literature. Most of these studies were based on numerous inventoried trees over large study areas. However, none of them considered bark stripping concurrently with all.

and sometimes as a factor with low or even undetectable effects (Völk, F.H. 1999; Zidar 2011; Månsson and Jarnemo 2013; Jarnemo et al. 2014). Accordingly, differing strategies have been proposed to mitigate BS. Some advocate controlling the deer populations, others prefer mitigating forest sensitivity by reducing spruce areas and promoting a rich herbaceous layer. The observed discrepancies among the studies cited above are likely due to the variations in spatial and temporal scales, and in the variables considered.

In the work reported here, we made use of a long-term survey covering contrasting environmental conditions and deer abundance to untangle the effects of the main drivers. Our database consisted of annual reports on the proportions of Norway spruce trees affected by new BS damage. More than 50000 trees were monitored over an area of $6.000 \mathrm{~km}^{2}$, of which $2.575 \mathrm{~km}^{2}$ are forest, for 13 years in contrasting environmental conditions and deer abundance levels. We associated this database with a broad range of factors that influence BS (Table 1). Bark stripping mitigation strategies are discussed based on the findings.

\section{Materials and methods}

\section{Study area}

The study area was located in Wallonia and covered the whole regional population range of red deer $\left(2.575 \mathrm{~km}^{2}\right)$. The area was $58 \%$ forest, and pasture dominated the agricultural areas (Fig. 1). The relief consisted of high plateaus carved by narrow valleys. Elevation ranged between 140 and $694 \mathrm{~m}$ (a.s.l.). Human population density was low $(<50 /$ $\mathrm{km}^{2}$ ). Environmental conditions and tree damage rates varied significantly over relatively short distances. Harsh conditions and severe damage were associated with high elevations. Only $3 \%$ of spruce standing volume was damaged below $400 \mathrm{~m}, 6 \%$ between 400 and $500 \mathrm{~m}$, and $14 \%$ above $500 \mathrm{~m}$ (Alderweireld et al. 2015).

Mean temperature ranged between $7.5^{\circ} \mathrm{C}$ and $9{ }^{\circ} \mathrm{C}$, and the number of frost days ranged between 90 and 120. Mean snow cover duration varied from 25 days at the lowest altitude to more than 60 days at the highest altitude. Mean annual precipitations, rather evenly distributed during the year, varied from 800 to $900 \mathrm{~mm}$ to more than $1300 \mathrm{~mm}$ (Tricot et al. 1994).

Coniferous stands covered $64 \%$ of the total forest area but ranged from $25 \%$ below $300 \mathrm{~m}$ to $84 \%$ above $500 \mathrm{~m}$. Pure spruce stands accounted for $79 \%$ of coniferous stands and were almost exclusively even-aged (93\%) and managed with a final clear-cut around age 60-80 years. Douglas fir, 


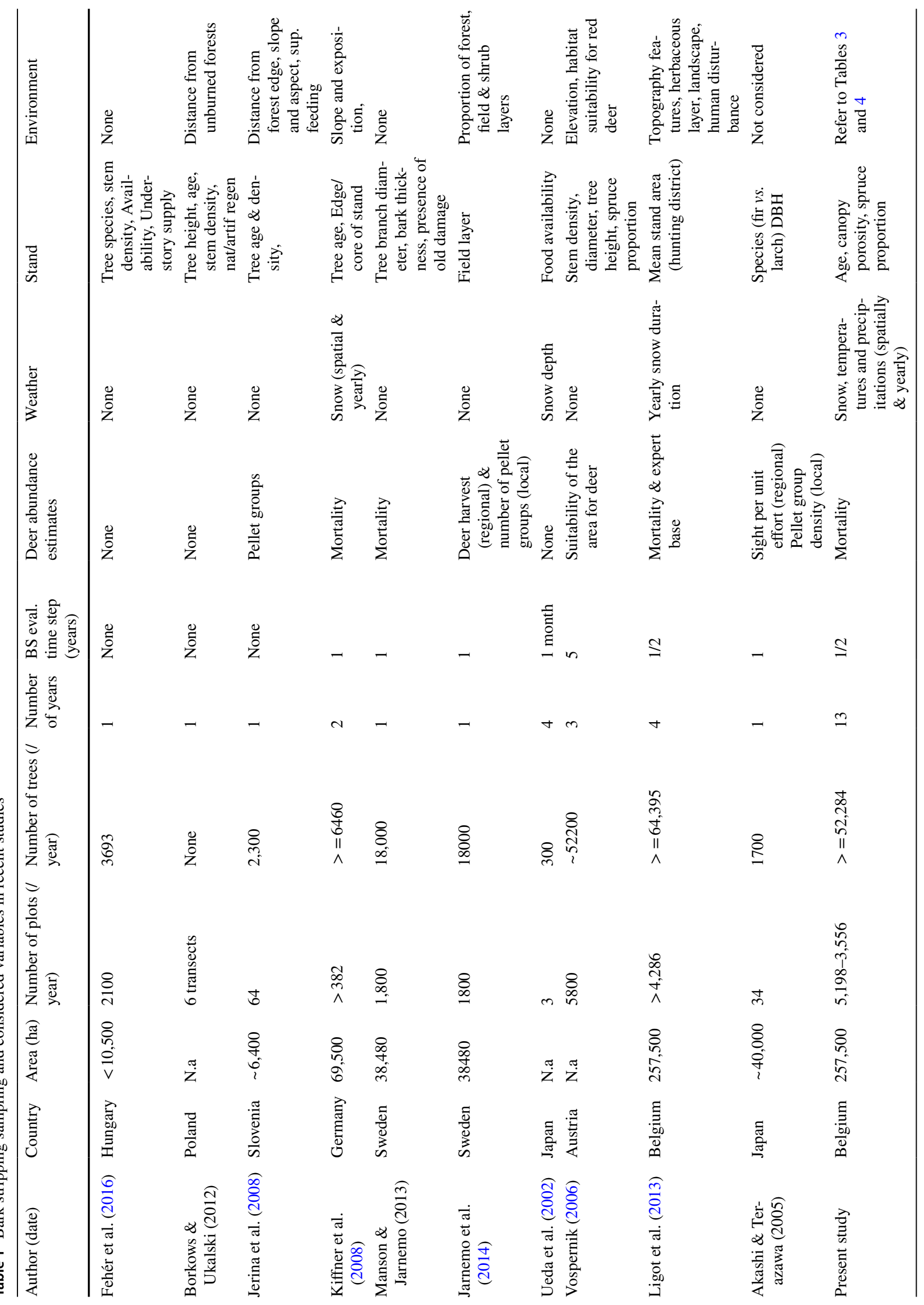




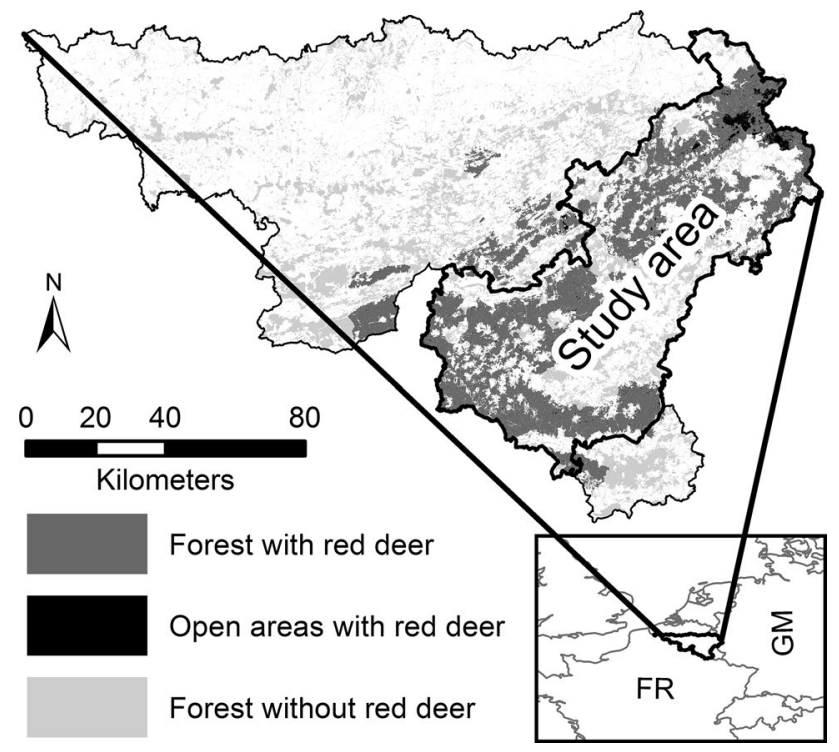

Fig. 1 Delimitation of the study area. Forests are light gray outside the red deer distribution area and dark gray inside the red deer distribution area. Open areas occupied by deer are black

the second most abundant coniferous species, was present on around $5 \%$ of the total forest area, $60 \%$ in pure stands and $40 \%$ mixed with spruce (Alderweireld et al. 2015). Spruce and Douglas stands were dense (mean basal area $39 \mathrm{~m}^{2} / \mathrm{ha}$, mean volume $419 \mathrm{~m}^{3} / \mathrm{ha}$ ) with a very sparse herbaceous layer, except in the oldest stands and during the 5 years after a clear-cut, where a lush herbaceous layer could develop until canopy closure (Alderweireld et al. 2015). Other main species were beech (Fagus sylvatica L.) (10\%), oak (Quercus petraea (Matt.) Liebl. and Q. robur L.) (11\%) and other broadleaves $(15 \%)$, mainly managed in continuous cover forestry and natural regeneration.

No precise red deer estimates were available for the study zone, but estimations of the forest service (Département de la Nature et des Forêts) ranged between 0 and 9 red deer per $\mathrm{km}^{2}$ (Ligot et al. 2013). Abundance indices, derived from spotlight counts (Garel et al. 2010), are computed in an increasing number of hunting districts. Their purpose is to inform changes in red deer abundance in time, but with no indications on absolute abundance, since the proportion of observed deer is unknown and differs between sites.

The red deer is a capital-breeder species (Jönsson 1997). In Wallonia, its natural mortality is low and the fertility rate is near-constant (Bertouille and de Crombrugghe 2002; Bertouille et al. 2015). Its abundance is thus almost exclusively shaped by hunting history. The numbers of red deer culled by hunters is an economic balance. Substantial fees may be charged to hunting associations that do not reach minimum culling quotas decided yearly and enforced by the forest service. However, hunting associations have an interest in keeping abundant deer populations to make or keep their hunting grounds financially attractive.

\section{Bark stripping inventory}

The inventory was based on a square grid of side $200 \mathrm{~m}$ (Fig. 2a). Sampling plots were installed at the grid intersections when located in stands of Norway spruce or Douglas fir. The inventory focused on young coniferous stands (8-36 years old) highlighted in the literature as the most sensitive to BS (Vospernik 2006; Jerina et al. 2008; Alderweireld et al. 2015). Because previous studies highlighted the greater sensitivity for stands 8-36 years old, we focused on this age class (Fig. 2a). Focusing on the most sensitive stands enabled to increase the sampling rate for the most relevant conditions. The semi-permanent sampling plots were inventoried every year between 15 April and 15 May. Plots located in stands older than 30 years for Douglas fir and 36 years for Norway spruce were abandoned, and new plots were installed at the grid intersections where Douglas fir or Norway spruce reached 8 years of age.

A sampling plot was installed at each grid intersection located in sensitive stands. The sampling plots were composed of three $10 \mathrm{~m}$ radius sub-plots. If there were sensitive trees in the first subplot, up to six sensitive trees closest to the centers of each $10 \mathrm{~m}$ radius sampling plots were inventoried (Fig. 2b). The center of the first sub-plot was located at the grid intersection, the two others $20 \mathrm{~m}$ from each other in the north direction.

Every inventoried tree was individually identified, and the number of bark-stripped trees was registered. At the installation of the plot, fresh damage ( $<12$ months) was differentiated from older damage by the absence of a healing bead (around the scar) and white resin (always sticky when caused in winter). In the subsequent years, the previous inventories helped operators tell fresh stripping marks even more confidently. The presence of teeth marks differentiated winter from summer bark stripping. During summer, bark was smooth and adhered weakly to the stem. It was pulled off in strips, and teeth marks were not visible. Table 2 shows the numbers of trees and plots inventoried and the mean bark stripping rates yearly.

\section{Explanatory variables}

Environmental variables were estimated at the plot level or at a larger geographic level when estimations at a finer scale were impossible or inconsistent. Choice of variables was guided by the literature (Ueda et al. 2002; Verheyden et al. 2006; Jerina et al. 2008; Kiffner et al. 2008; Månsson and Jarnemo 2013; Ligot et al. 2013; Jarnemo et al. 2014; Fehér et al. 2016) and by data availability for the study area. 
Fig. 2 Sampling design for the bark stripping inventory: a Location of sampling plots on the square grid, $\mathbf{b}$ Measure of the bark stripping rate inside a sampling plot. Non-sensitive trees were not considered nor represented in this figure. Inventoried stands are plantations

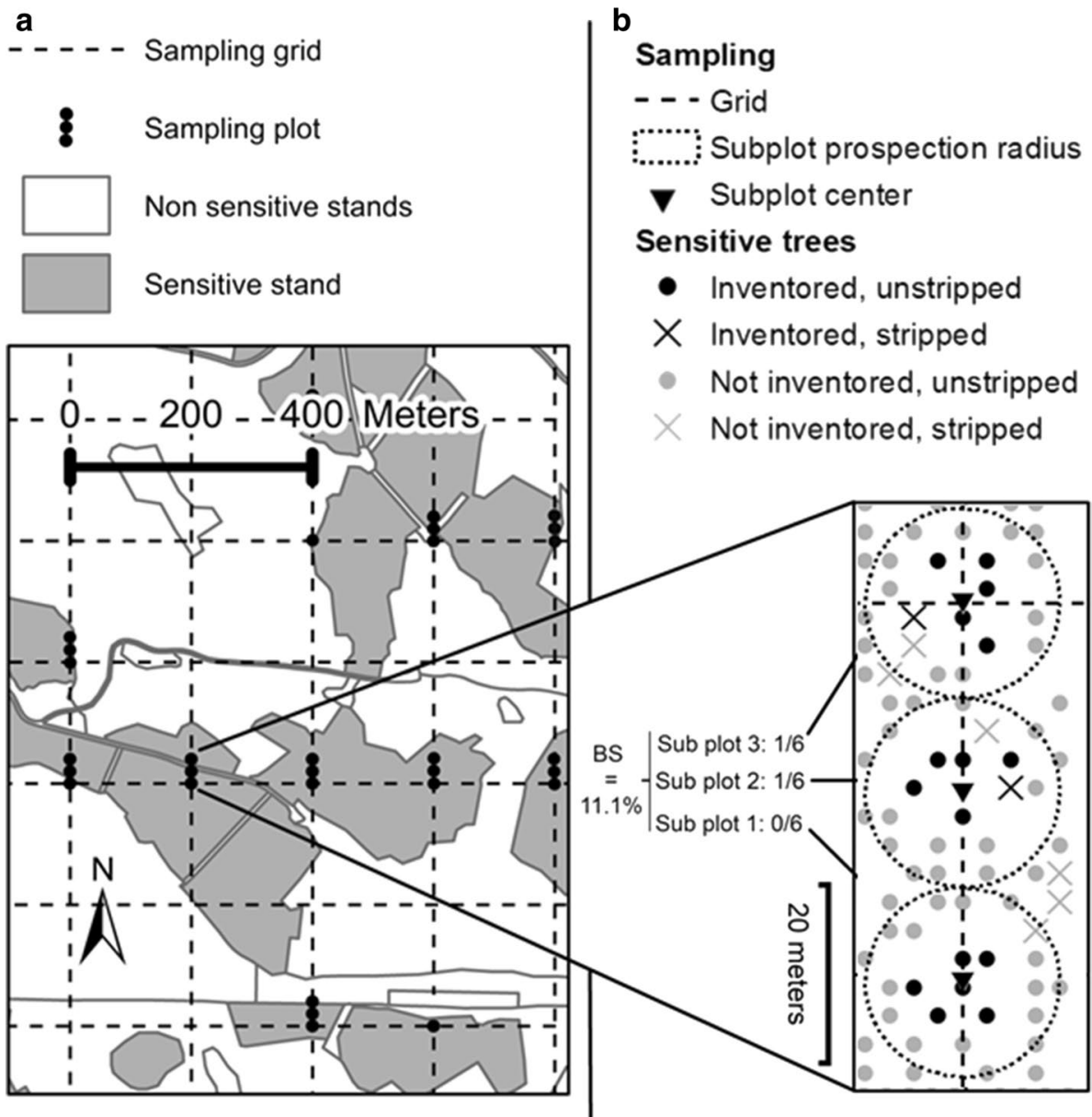

Table 2 Number of plots and trees inventoried and mean bark stripping rate in winter (BSW) and summer (BSS)

\begin{tabular}{|c|c|c|c|c|c|c|c|c|c|c|c|c|c|}
\hline Year & 2004 & 2005 & 2006 & 2007 & 2008 & 2009 & 2010 & 2011 & 2012 & 2013 & 2014 & 2015 & 2016 \\
\hline Number of plots & $4.10^{3}$ & $5.10^{3}$ & $5.10^{3}$ & $5.10^{3}$ & $5.10^{3}$ & $5.10^{3}$ & $4.10^{3}$ & $4.10^{3}$ & $4.10^{3}$ & $4.10^{3}$ & $4.10^{3}$ & $4.10^{3}$ & $3.10^{3}$ \\
\hline Number of trees & $6.10^{4}$ & $7.10^{4}$ & $8.10^{4}$ & $7.10^{4}$ & $7.10^{4}$ & $7.10^{4}$ & $6.10^{4}$ & $6.10^{4}$ & $6.10^{4}$ & $6.10^{4}$ & $6.10^{4}$ & $6.10^{4}$ & $5.10^{4}$ \\
\hline BSW (\%) & 2.8 & 2.1 & 4 & 1.5 & 2.8 & 3.5 & 3.9 & 2.5 & 1.7 & 3.5 & 1.8 & 2.3 & 2.3 \\
\hline BSS (\%) & 0.7 & 0.6 & 0.7 & 0.5 & 0.8 & 1 & 0.9 & 0.9 & 0.5 & 0.7 & 0.8 & 0.7 & 0.7 \\
\hline
\end{tabular}

\section{Red deer abundance and spatial distribution}

The number of yearly culled red deer (source: forest service of Wallonia, DNF) was used as an abundance index. This information reflects general population trends, though potentially time-lagged (see Fryxell et al. 1991, Solberg et al. 1999 and Forchhammer et al. 1998 in Kiffner et al. 2008 and Ueno et al., 2014 in Jarnemo et al., 2014). During the 13 years covered by the survey, this metric was collected with a standard method to reduce operator bias. Red deer mortality was recorded at the level of forest district (1.350 ha on average). In the study area, these districts were representative of the individual red deer home ranges (Licoppe 2006), although some individuals ranged over much larger areas, especially in winter
(Licoppe and Lievens 2010). For every culled red deer, an officer of state forest agency delivered a certificate after in situ verification. The venison could only be transported with an irremovable identification tag. Hunters had an incentive to report all red deer mortality since they must reach a minimum culling quota each year. In this way, both natural and culling mortality was exhaustively recorded in a state database.

\section{Climate}

Temperature and precipitation variables were extracted from the E-OBS $0.1^{\circ}$ resolution daily gridded dataset (Haylock et al., 2008) to reflect food limiting periods. Number of frost and ice days (Tmin $<0 \mathrm{C}$ and $\mathrm{Tmax}<0 \mathrm{C}$ ), and of heavy 
and very heavy precipitation days (10-20 $\mathrm{mm})$ were computed to characterize winter food scarcity and adverse climatic conditions. Summer drought was estimated as the difference between precipitations and potential evapotranspiration (ETP) of Hargreaves (SPEI package: Beguería and VicenteSerrano., 2017). A $5 \mathrm{~km}$ resolution index of winter snow cover was characterized yearly using the weighted average of the monthly snow cover from MOD10CM and MYD10CM (Hall and Riggs 2015, 2016) datasets weighted by the number of days of the month. This index is equivalent to the percentage of time for which an area was covered by snow from early November to end of April. The measurements of two weather stations recording snow depth daily were also used to estimate the number of snow days, defined as days with snow deeper than $2 \mathrm{~cm}$. This last index varied in time but not in space.

\section{Forest and stand characteristics}

The proportions of main tree species (i.e., oak, common beech, Norway spruce and Douglas fir) and the proportion of broadleaves were estimated in a $100 \mathrm{~m}$ buffer around plots from a supervised pixel-based classification forest map (Bolyn et al. 2018). A yearly index of beechnut and acorn availability was estimated, combining a yearly ordinal estimation of oak and beech fruit production from the DNF (Comptoir Forestier) combined with beech and oak mean basal area (DNF: Comptoir Forestier and IPRFW). The gap fraction was computed from a high-density LiDAR point cloud (acquired in 2013 and 2014 at the region level; https://geoportail.wallonie. be) considering a bottom limit of $3 \mathrm{~m}$. The gap fraction was estimated in a radius of 25, 50, 75 and $100 \mathrm{~m}$ around the centers of sampling plots with the gap_fraction_profile available in the lidR 2.0.3 package (Roussel \& Auty., 2018).

\section{Landform and soil}

Elevation and several landform variables were computed in a $150 \mathrm{~m}$ radius around plot centers from a $10 \mathrm{~m}$ resolution digital elevation model (https://geoportail.wallonie.be). Topographic position index (TPI) was computed as the ratio of the plot center altitude to the mean altitude in the plot buffer. Ten landform classes were defined using the Morphometric Features tool from the SAGA-GIS Morphometry library (V6.0.0) (Weiss 2000; Conrad et al. 2015). Landform characterization was based on multiscale TPI evaluations. Landform was also classified in three radiative sectors based on slope angle and orientation as a proxy of solar radiation received by the hillside (Delvaux and Galoux 1962). The proportion of oligo-humid soils was calculated in a $100 \mathrm{~m}$ radius around plots from the numerical soil map of Wallonia (Legrain et al. 2011). These soils were widespread in the highlands and presented severe constraints for vegetation growth compared to the dominant well-drained acid brown soils.

\section{Land use}

Main land use classes (i.e., pastures, cultivated areas, urban areas and forest) and Euclidian distances from these features were derived from the 1:10,000 land use map Top10Vector (https://geoportail.wallonie.be). Euclidian distance from nearest roads was derived from the open street map layer available under the Open Database License (https://www. openstreetmap.org).

\section{Statistical analysis}

A model was adjusted in three steps to predict the proportion of freshly ( $\leq 1$ year) bark-stripped trees at the plot level (BS), during winter (BSW) and during summer (BSS). First, two binomial GLMs (generalized linear models; logit link) were adjusted with LASSO regularization (Least Absolute Shrinkage and Selection Operator) on BSW and BSS. They were processed using the $c v$.glmnet function of the glmnet package version 2.0-18 (Friedman et al., 2010). This first step identified the best explanatory variables for BSW and BSS. Secondly, as best variables were common to BSW and BSS, a unique GLM was fitted with a binary factor expressing seasons (winter or summer). Finally, as some factors had a clearly nonlinear effect on BS, smoothing functions were applied to these factors using a GAM (generalized additive model, Eq. 1 with the $m g c v$ package 1.8-28 (Wood 2011, 2017). Statistical analysis was carried out with $R$-3.5.2 software (R Core Team, 2019). Equation 1 describes the formulation of the final GAM composed of three parts. The first part is the base of the model applied to winter and summer BS. The second part only applied to winter BS (BSW). The third part only applied to summer BS (BSS). Only the significant variables were kept at each step of the modeling process.

$$
\operatorname{logit}(B S)=\frac{\sqrt{\text { intercept }+\sum_{i} f_{i}\left(x_{i}\right)+\sum_{i} S_{i}\left(x_{i}\right)}+\operatorname{Win}_{0}^{1}\left(\sum_{i} f_{i}\left(\text { climatevariable }_{i}\right)+S(\text { standage })\right)}{\text { Base }}+
$$


$\operatorname{Sum}_{0}^{1}($ intercept $+S($ standage $))$

Summer

Equation 1 Formulation of the general additive model (GAM) for winter and summer BS estimation. The first part is the base of the model applied to winter and summer BS. The second part only applied to winter BS. The third part only applied to summer BS. Binary factors (Win and Sum) activated either the second part for BSW or the third part for BSS. $f$ denotes linear functions and $S$ smoothing functions.

The odds ratios (ORs) were computed for every variable as the ratio of predicted BS for the variable in its 5th and 95th percentile range (Eq. 2) Smoothed variables had a quasi-monotonous response. The OR thus allowed an effective comparison of each variable's importance in the model based on its relative effect on BS estimation. Stand age was the only variable with a unimodal response of BS predictions. ORs were thus computed between the maximum and minimum BS values for that variable.
$O R_{i}=B S_{i}^{95 \text { th percentile }} / B S_{i}^{5 \text { th percentile }}$

Equation 2 Odds ratio of $i$ th variable of the GAM BS model.

\section{Results}

Parametric coefficients of the final model are presented in Table 3, and the approximations of smoothed term significance in Table 4. Column 6 in Tables 3 and 4 present the ORs of variables for a variation of the corresponding variable presented in Column 5. Relative values of all variable ORs are presented in Column 8. This allows a proper comparison of the relative power of each variable in the predictive effect on BS.

Figure 3 illustrates the extent to which the variables can influence the BS predictions of the GAM (based on the ORs

Table 3 Estimated parametric coefficients of the GAM

\begin{tabular}{|c|c|c|c|c|c|c|c|}
\hline & Winter & Summer & Estimate & Std. error & Variable range & OR & $\mathrm{OR} \mathrm{OR}_{\max }$ \\
\hline Proportion of spruce in sampled trees & 1 & 1 & 0.801 & 0.027 & $0-1$ & 2.18 & 0.4 \\
\hline Deeply incised valley bottom & 1 & 1 & -0.418 & 0.047 & $0-1$ & $1 / 1.50$ & 0.3 \\
\hline Proportion of deciduous (<100 m buffer) & 1 & 1 & 0.63 & 0.036 & $0-0.65$ & 1.47 & 0.2 \\
\hline Gap fraction $(<25 \mathrm{~m}$ buffer $)$ & 1 & 1 & -0.502 & 0.035 & $0.05-0.81$ & $1 / 1.45$ & 0.2 \\
\hline Proportion of oligo-humid soils ( $<100 \mathrm{~m}$ buffer) & 1 & 1 & 0.183 & 0.018 & $0-1$ & 1.19 & 0.2 \\
\hline Open slopes & 1 & 1 & 0.133 & 0.016 & $0-1$ & 1.14 & 0.2 \\
\hline Intercept & 1 & 1 & -5.393 & 0.04 & & & \\
\hline Number of frost days & 1 & & 0.011 & 0 & $27-111$ & 2.43 & 0.4 \\
\hline Beech mast index & 1 & & -0.008 & 0.001 & $0-32.73$ & $1 / 1.31$ & 0.2 \\
\hline Snow cover ${ }_{\text {MODIS }}$ & 1 & & 0.002 & 0 & $2.58-64.17$ & 1.14 & 0.2 \\
\hline Intercept $_{\text {summer }}$ & & 1 & -0.537 & 0.033 & $0-1$ & $1 / 4.83$ & 0.8 \\
\hline
\end{tabular}

Terms apply for BSW and BSS only when the column of corresponding season contains value 1 for the parameter. The odds ratios (ORs) are presented for a single variable change in variable range. The last column presents ORs relative to the maximum OR of the model. They were computed based on BSW variations except for summer-only terms

Table 4 Approximated significances of smoothed terms of the GAM

\begin{tabular}{|c|c|c|c|c|c|c|c|c|}
\hline & Unit & Winter & Summer & edf & Ref.df & Variable range & OR & $\mathrm{OR}_{\mathrm{OOR}}$ max \\
\hline Red deer abundance index & $\begin{array}{l}\text { Number of culled } \\
\text { red deer } / \mathrm{km}^{2}\end{array}$ & 1 & 1 & 8.674 & 8.968 & $0-26.94$ & 5.90 & 1.0 \\
\hline Distance from cultivated areas & $\mathrm{m}$ & 1 & 1 & 8.284 & 8.828 & $0-3349$ & $1 / 2.82$ & 0.5 \\
\hline Distance from roads and urban areas & $\mathrm{m}$ & 1 & 1 & 7.921 & 8.697 & $516-3443$ & 1.97 & 0.3 \\
\hline Altitude & $\mathrm{m}$ & 1 & 1 & 8.382 & 8.884 & $297-522$ & 1.62 & 0.3 \\
\hline Stand age $_{\text {summer }}$ & year & 1 & 0 & 5.454 & 6.496 & $12-36$ & $1 / 5.53$ & 0.9 \\
\hline Stand age winter $_{\text {}}$ & year & 0 & 1 & 6.512 & 7.497 & $21-36$ & $1 / 2.08$ & 0.4 \\
\hline
\end{tabular}

Terms apply for BSW and BSS only when the column of corresponding seasons contains value 1. Edf is the estimated degree of freedom of the model, and Ref.df is the reference degree of freedom. The odds ratios (ORs) are presented for a single variable change in variable range. The ratios of OR to the maximum OR of the model are in the last column (computed for BSW except for summer-only terms) 
Fig. 3 Effects of explanatory variables on BS prediction of the final GAM. Odds ratios were computed using Eq. 2. For mitigating variables (i.e., odds ratios smaller than one), inverse values were used for easier comparison with exacerbating variables (i.e., odds ratios higher than one)

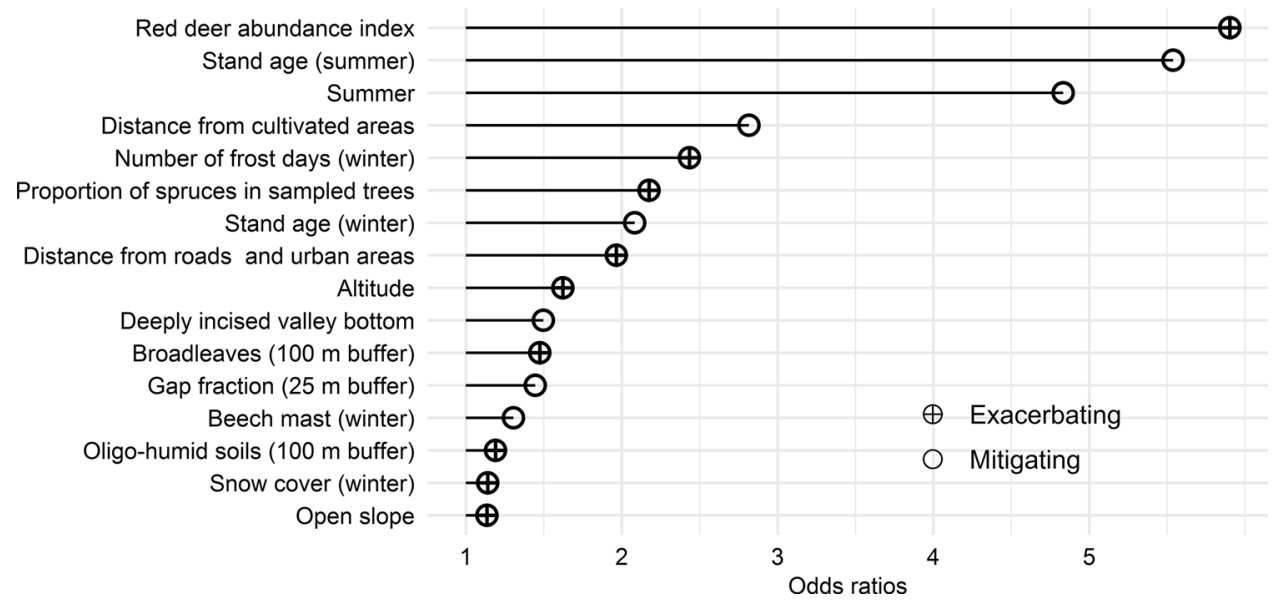

for increasing stand age. Summer BS in 12 years old stands (95th percentile) was $550 \%$ of BS rate in 36 years old stands (5th percentile), and winter BS in 21 years old stands was $200 \%$ of BS rate in 36 years old stand. The summer variable was a mitigating variable; winter BS rate is $480 \%$ of summer BS rate. The GAM highlighted eight variables which could individually induce changes of BS rates of more than $200 \%$ in their observed range of variations (ORs $>=2$ ) the of Column 8 in Tables 3 and 4). The variables are presented in decreasing order of importance. It allows to compare as well exacerbating variables (i.e., with an $\mathrm{OR}>1$ ) as mitigating variables (i.e., with an $\mathrm{OR}<1$ ). For example, the red deer abundance index was an exacerbating variable the caused a BS increase of $590 \%$ for a change from the 5 th to the 95th percentile of this variable. The stand age is a mitigating variable. Both summer and winter BS rates decreased
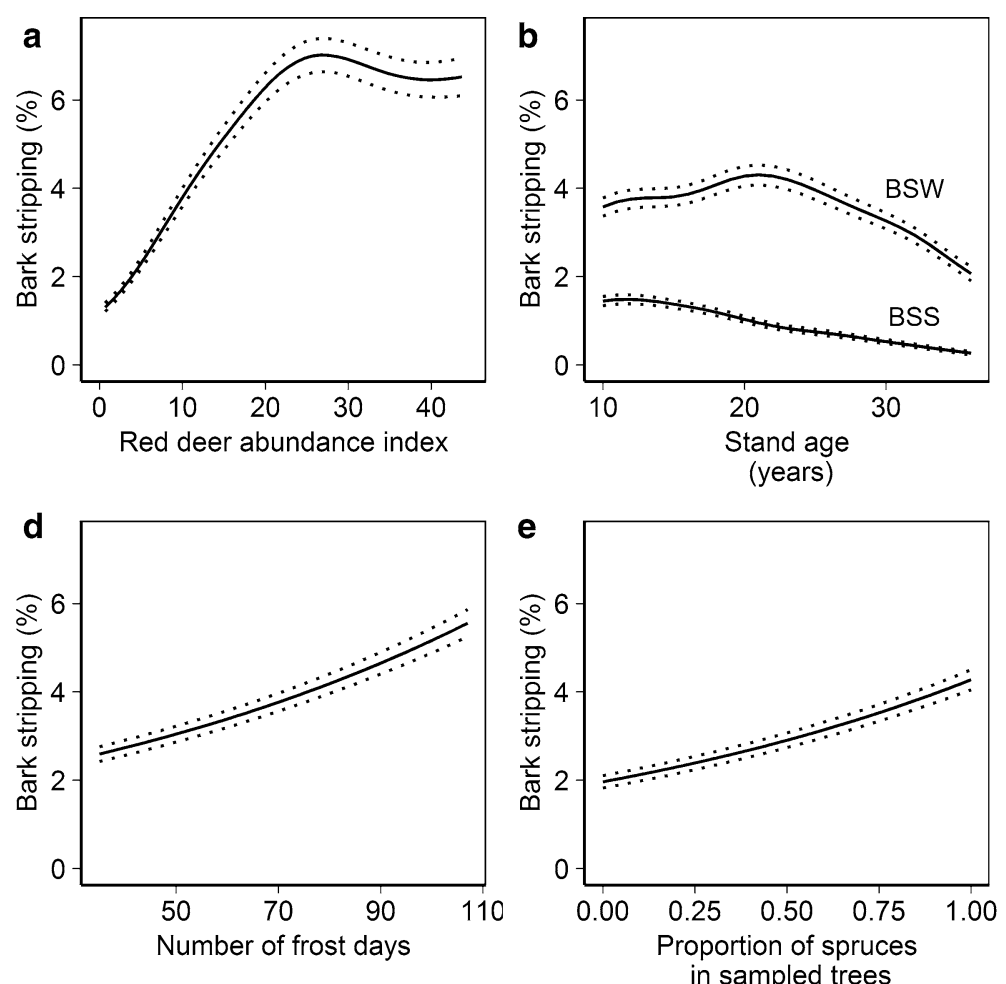

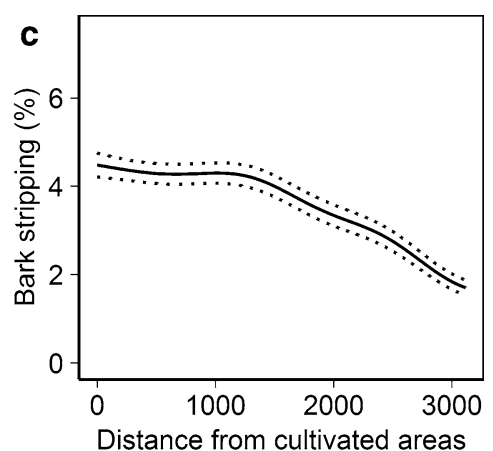

(m)

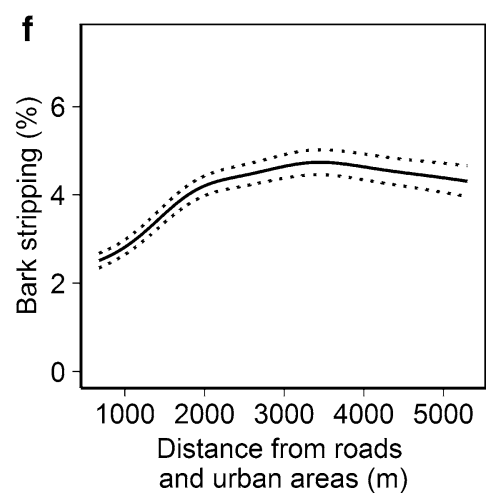

Fig. 4 Bark stripping estimation of the GAM for single variable variations: red deer abundance index (i.e., number of red deer culled per $10 \mathrm{~km}^{2}$ ) a, stand age $\mathbf{b}$, distance from cultivated area $\mathbf{c}$, number of frost days $\mathbf{d}$, proportion of spruces in the plot $\mathbf{e}$, and cumulated dis- tances from roads and urban areas $\mathbf{f}$. The estimated BS was by default winter bark stripping (BSW). Dotted lines indicate the confidence intervals of the estimates $(\alpha=0.05)$ 
most important being the red deer abundance index. Eight variables could only induce changes of BS rates smaller than $200 \%$. These variables are also significant but less determinant for the quantitative estimations of BS rates. Their effect is consistent with the literature and helps to better understand BS underlying causes.

Fig. 4 shows the BS response to variables with a nonlinear effect (smooth). BS rate increased with red deer abundance index up to a threshold of 25 (Fig. 4a). BSW peaked at 21 years. BSS decreased with age from 12 years (Fig. 4b). BS decreased with increasing distance from cultivated areas (Fig. 4c). By contrast, BS decreased when cumulated distance from roads and urban areas fell below $1 \mathrm{~km}$ (Fig. 4e). BSW increased with the number of frost days during the winter before the inventory (Fig. 4d).

The GAM was adjusted at plot level on 110,296 observations and explained $17.9 \%$ of the deviance. The adjusted Rsq was 0.08 at plot level and 0.43 at forest block level. The forest blocks were defined by Ligot et al. (2013), considering the home range of red deer populations, separated by significant obstacles such as roads, railways and waterways (Fig. 5a). At the region level, yearly variations of BSW were correctly predicted by the GAM with an Rsq of 0.7. For BSS, adjusted Rsq was 0.26 (Fig. 5b).

\section{Discussion}

\section{Model evaluation}

The goodness of fit of the GAM was similar to that of previous studies at same resolution (Kiffner et al. 2008; Ligot et al. 2013) (Fig. 5a for BSW). The yearly variations of BSW were satisfactorily estimated at the regional level (Fig. 5b). Modeling at plot level untangled the effects of variables affecting BS at a finer spatial scale (Fig. 2 and Fig. 3). Goodness of fit computed at sampling plot level was weak, but BS was modeled with a yearly time step and in very homogeneous stands (i.e., Norway spruce and Douglas fir stands between 8 and 36 years old). In the literature, studies with better fit considered a broader tree age range, more tree species and often aggregated BS damage caused over several years (Table 1). Similar goodness of fit was obtained when equivalent spatial and temporal resolution were considered with similar inventoried stands (Kiffner et al. 2008).

\section{Variable interpretation}

\section{Population abundance and spatial distribution}

Most BS studies have found relations with deer abundance (Akashi and Terazawa 2005; Vospernik 2006; Jerina et al. 2008; Kiffner et al. 2008; Ligot et al. 2013; Jarnemo et al. 2014), some at local level but not at regional level (Akashi and Terazawa 2005; Jarnemo et al. 2014), suggesting that local high-density clustering of red deer and susceptibility of stands to BS could impact BS outbreaks unevenly. Our large spatial and temporal scale of investigation with its halfyear resolution took these effects into account exhaustively, with a high resolution in space and time. Furthermore, using deer cull on a large database could give better results since this indicator can be locally time-lagged (Allen et al. 2014). These results thus lend a high degree of confidence to the predominant effect of red deer abundance on BS rate in young Norway spruce and Douglas fir.
Fig. 5 Comparison between observed and fitted yearly BSW aggregated at the forest block level a. Yearly variations of observed and fitted mean BSW and BSS in the study area $\mathbf{b}$
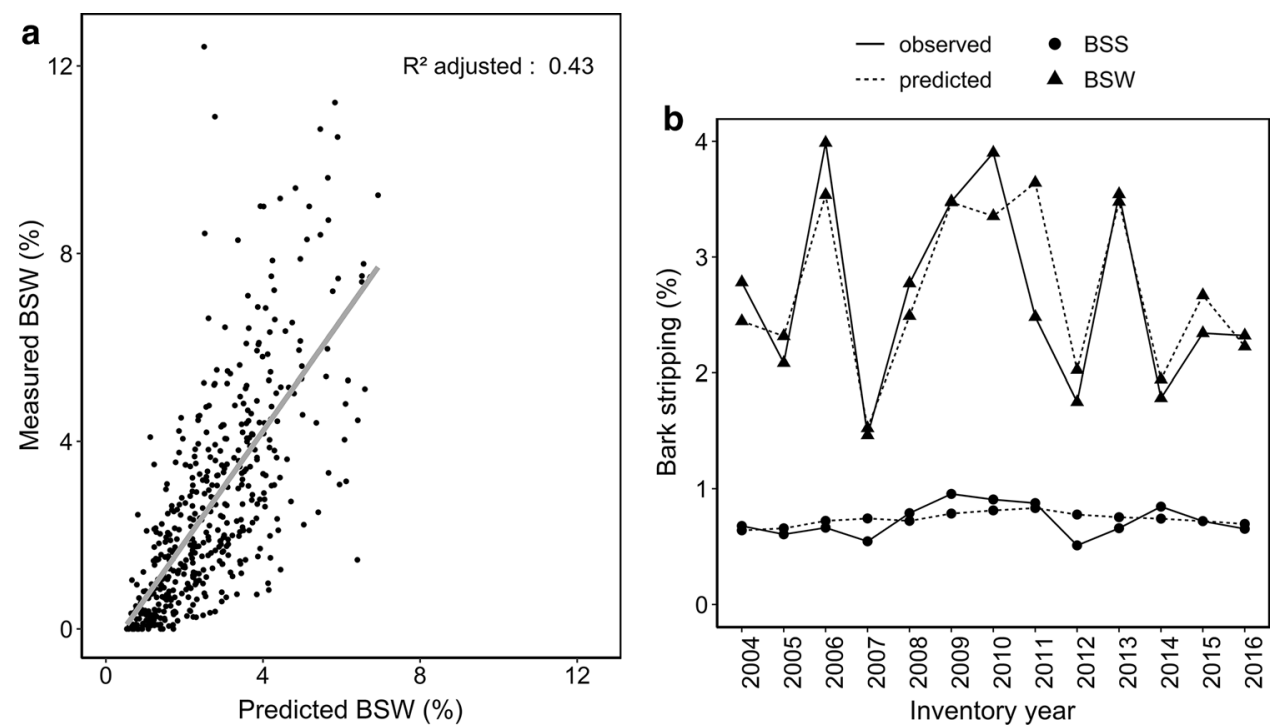
BS rate fluctuations with distances from agricultural and human features also reflect large-scale red deer population distribution. Licoppe and Lievens (2010) demonstrated that red deer that usually occupy the center of forests make regular journeys to pastures at the edge of large forest areas. Red deer thus spend more time in forest stands near the pastures than in more remote ones. In addition, limited day movement in fragmented forest landscapes could also exacerbate BS (Jarnemo et al. 2014).

Human presence strongly impacts ungulate behavior and habitat selection (Allen et al. 2014). The effects on local deer abundance can be stronger than natural factors (Jerina, 2012). Regular human presence in forests for leisure activities locally decreases red deer abundance and BS occurrence (Drimaj et al. 2018). Although forest density in the study area was high, the forest, surrounded by densely populated regions, was much used for leisure activities (Colson et al. 2010). The law restricts movement to roads and paths (Colson et al. 2010), and the numbers of visitors rapidly falls off with increasing travel distance regardless of the means of travel used ( $\mathrm{Li}$ et al. 2016). Deer thus frequent and cause more damage in those areas furthest from roads and urban settlements.

\section{Climate and mast}

Closed coniferous stands are preferred especially during winter, when hiding cover and food resources are scant in broadleaved stands and because of higher snow interception and thermal cover in evergreen stands (Licoppe and De Crombrugghe 2003; Akashi and Terazawa 2005). Numerous quantitative studies highlight the triggering effect of snow covering the ground on bark peeling intensity due to reduced food availability (Ueda et al. 2002; Verheyden et al. 2006; Vospernik 2006; Kiffner et al. 2008; Honda et al. 2008; Ligot et al. 2013; Arnold et al. 2018), and an increased energy demand for moving and maintaining body heat (Ueda et al. 2002; Verheyden et al. 2006; Rivrud 2013).

The stronger effect of number of frost days than of snow cover on BSW may seem a surprising observation, but only Ueda et al., (2002) have sought a link between snow depth and food availability, with the hypothesis that only vegetation above snow surface was available. Kiffner et al. (2008) assessed the snow depth-BS relation and found a significant effect of snow only when its depth exceeded $1.500 \mathrm{~mm}$. Such snow depth never occurred in our study area. Verheyden (2006) evidenced dramatic BS in regions with cold, snowy winters. We deduce that for the light snow in the study area, food availability decreased especially when snow falls were combined with several days of frost, causing snow crusting. Sweeping away loose snow from herbaceous vegetation is easy for deer.
Snow data selected in the model were taken from satellite observations. They allow a spatial characterization and thus had greater predictive power than the records of snow cover from the two field stations in the study area. Unfortunately, satellite observations lack accuracy especially during months with heavy cloud cover, thus probably decreasing the predictive power of the variable. Furthermore, the number of frost days and snow cover are correlated $(r=0.44)$, and so the frost day variable can weaken the significance of the snow variable.

Observing a mitigating effect of beechnut and acorn abundance is further evidence consistent with the food resource hypothesis (Verheyden et al. 2006). When abundant, this mast forms a high proportion of the red deer diet, greatly increasing red deer body mass (Pellerin et al. 2014), and decreasing consumption of usual food items, particularly woody twigs (Picard et al. 1991; Saïd et al. 2015). Bark and woody twigs have quite similar nutrient contents (Rademacher 2005) and even a thin snow layer on the ground dramatically increases woody twig consumption (Picard et al. 1991). Forest fruit abundance is rarely monitored. To our knowledge, this study is the first to highlight their effect on ungulate damage. Abundant food resources in broadleaves during masting could also draw red deer from coniferous stands, thereby helping to reduce BS.

\section{Stand characteristics}

Bark thickness and prehensility have determinant roles in BS sensitivity as shown by the seasonal and multi-year timing of BS outbreaks for several species. Bark thickens, stiffens, adheres more strongly to the trunk and is less palatable when trees are growing. These changes reduce sensitivity to BS (Gill, 1992; Jarnemo et al., 2014; Jerina et al. 2008; Månsson and Jarnemo 2013; Vospernik 2006; Borkowski and Ukalski 2012; Honda et al. 2008). Tree species with early-thickening bark have a short bark peeling sensitivity period, while slowly thickening bark species stay sensitive up to age 60 years (Fehér et al. 2016). Beech bark is difficult to peel in winter (Vospernik 2006) and is thus more severely affected in summer (Saint-Andrieux et al. 2009).

The difference in stand age peaks between winter BS (BSW) and summer BS (BSS) highlights variations in the prime importance of bark physical characteristics between seasons in coniferous stands (Vospernick. 2006). BS rate is shaped by a compromise between bark physical characteristics and deer abundance in stands. BSS seems mainly driven by bark and stem physical properties. In summer, deer tear off long strips of bark that must thus be thin and flexible (Nopp-Mayr et al. 2011; Borkowski and Ukalski 2012). Bark physical characteristics, especially prehensility, are thus of major importance for BSS (de Crombrugghe. 1965). During winter, bark is stiff and brittle and is removed 
in short flakes (Gheysen et al. 2011); bark thickness and adherence thus have less influence. Furthermore, the peak of BSW is consistent with the results of Trisl et al. (1999) and coincides with the age of the first clearing, often preceded by the pruning of all branches below $2 \mathrm{~m}$ (Perin and Hébert 2016), which was observed to exacerbate BS (Baders et al. 2017). It is suspected that red deer avoid stands with low branches when covered with snow because of poor thermal protection and restricted movement and prefer older stands, where low branches have been pruned and where cover is dense (Licoppe 2006).

BS rate is higher in stands with a higher spruce proportion. This effect is caused by the greater sensitivity of spruce, among the most severely affected species, despite being the most abundant in the study area. Since spruce has thinner bark with late suberization (Hébert et al. 2002), and no study has found evidence of any influence of bark chemical composition on stripping probability (Ando et al. 2003; Saint-Andrieux et al. 2009), we assume that spruce palatability is mainly guided by physical characteristics of the bark.

An exacerbating effect on BS of the broadleaf proportion in surrounding stands was also highlighted (Table 3). This result contrasts with those of Ligot et al. (2013) based on a coarser spatial resolution (first 4 years from the same bark stripping database used in the present study). However, it is consistent with the red deer habitat selection in the same region (Licoppe 2006). Red deer prefer coniferous stands to broadleaved stands, especially during winter. The exacerbating effect of broadleaf proportion on BS in coniferous stands is thus probably caused by higher red deer concentrations in less frequent or available coniferous areas. The positive variation found by Ligot et al. (2013) probably arises from a confounding effect of cold weather and coniferous proportions. Both are correlated positively with altitude (Alderweireld et al. 2015). The present study considered these three variables at the plot level instead of the forest block level defined by Ligot et al. (2013) to better untangle their respective effects.

Despite its limited effect, broadleaf proportion is important for understanding the underlying causes of BS and for its management implications. It confirms the importance of local habitat selection, which for food-independent reasons can outweigh the effect of food availability in the occurrence of damage. This observation was only possible by considering several variables at the most relevant spatial level. The strong confounding effect of the positive relation between conifer proportion and altitude can easily lead to the opposite conclusion, if not correctly untangled.

BS decreases with increasing gap fraction (GF). GF is related to three groups of variables: (i) GF is inversely related to the proportion of light reaching the ground, and thus to the food resource of the herbaceous layer, (ii) GF is inversely related to tree competition, and thus to bark thickening rate, and size of low branches, and (iii) GF is inversely related to the physical protection provided by coniferous stands against cold, snow and rain. Greater sensitivity of dense conifer stands to BS has been repeatedly reported (Fehér et al. 2016; Jerina et al. 2008; Vospernik 2006; Ligot et al. 2013). However, the strong correlation between these three groups of variables makes it hard to determine their relative influence on bark stripping (Vospernik 2006; Jerina et al. 2008). The effect of GF is weak compared with the other variables (Fig. 3). The $\mathrm{GF}$, computed in the smallest radius $(25 \mathrm{~m})$, was the most explanatory. The very local effect of GF and the strong relation between bark stripping and stand age shows that physical characteristics prevail over food resources of the herbaceous layer. This is also in line with Fehér et al. (2016), who observed bark stripping more frequently close to abundant herbaceous layer.

\section{Landform and altitude}

The effects of topography on BS were observed in several studies. Higher BS was observed for colder aspects, steeper slopes, and on convex landforms (Jerina et al. 2008; Kiffner et al. 2008; Nopp-Mayr et al. 2011). Underlying mechanisms could involve variations in habitat selection in relation with predation or with thermo-regulation; these mechanisms are still not clearly identified and may have opposing effects when considered at different scales. In this study, variations in elevation were narrower than in other studies. Unfavorable landforms could affect BS less since red deer can easily avoid them over short distances. Incised streams could be avoided because they hinder escape and because of exacerbated cold conditions in valley bottoms (Nopp-Mayr et al. 2011). In this study, the landform was composed of gentle slopes on the uplands carved by narrow valleys. Open slopes could thus be selected preferentially because they are less exposed to wind, offer dominant positions and are less hostile during thermal inversions than bottoms of narrow valleys (NoppMayr et al. 2011). However, as the slope effect highlighted was low, it should be interpreted with caution.

BS was correlated positively with altitude, probably mainly in relation with increasing winter severity. Unlike altitude, the spatial resolution of climate variables used to predict BS was rather coarse (about $11 \mathrm{~km}$ for temperature, $5 \mathrm{~km}$ for snow and $1 \mathrm{~m}$ for altitude). Variations in climate characteristics between plots were thus poorly captured. Part of the missing climate variation was probably 
expressed by altitude, better differentiating BS at plot level.

\section{Soil}

Higher BS was estimated for plots surrounded by high proportions of oligo-humid soils. Oligo-humid soils are among the most unproductive of Wallonia: their climax vegetation is the Medio-European acidophilous Quercus forests with Deschampia flexuosa and Vaccinium myrtillus for temporary waterlogging, with Sphagnum spp. and Molinia caerulea for permanent waterlogging. The herbaceous vegetation is particularly unpalatable for deer and often blocks the development of other woody vegetation. It contrasts with dominant well-drained acid brown soils with Medio-European collinear woodrush beech forests as climax vegetation, where much greater food resources are found in forest gaps and clear-cuts (Claessens 2017).

\section{Management implications}

The factors that most influence BS were analyzed concurrently at high spatial and temporal resolution and over a large study area. Their effects were untangled and their relative impact on BS assessed.

BS is essentially driven by red deer abundance, stand sensitivity and selection by red deer, and winter climate. The relative importance of the most explanatory variables clearly showed maintaining red deer abundance at an appropriate level to be the keystone of BS mitigation strategy in young coniferous stands. Since hunting is responsible for more than $90 \%$ of the mortality in calves and hinds, hunting programs are by far the most effective way to modulate BS.

Distribution of agricultural areas and human infrastructures influence BS over several kilometers, and forest management cannot easily act on these variables. Prevention of harassment by humans in areas of low timber potential and high ecological tolerance for red deer could help concentrate the impact of red deer where it is least detrimental. More locally, higher habitat selection for young coniferous thickets thwarts strategies for increasing herbaceous layers in surrounding areas. Reduction in conifer proportions will be counterproductive for the conserved coniferous stands (as the concentration of red deer would increase). Decreasing forest sensitivity to BS should thus target the sensitivity of the stand itself.

Decreasing spruce proportions in favor of other conifers such as Douglas fir can mitigate BS without negative consequences on the quantity and quality of timber. However, Norway spruce is a robust species and its substitution by other species is not possible on every site. Spruce is also less palatable to browsing than other coniferous species, including Douglas fir and is thus easier to install in areas with high browsing pressure.

Young coniferous thickets have a high sensitivity due to a combination of thermic cover, scarce food resources and physical characteristics of branches and bark. Early thinning to increase the herbaceous layer, branch size and bark thickness are suggested in several studies (Vospernik 2006; Jerina et al. 2008; Månsson and Jarnemo 2013; Jarnemo et al. 2014). Our results showed that the stand should be thinned earlier than 20 years old, before reaching commercial dimensions. However, for the production of quality timber, branch diameters must be less than $2 \mathrm{~cm}$. This value is exceeded when trees are planted more than $2 \mathrm{~m}$ apart (Hébert et al. 2002). Owing to the weak effect of the gap fraction variable, and the negative effect on timber quality (higher branch sizes and growth rings), we argue that such a measure would be counterproductive in regions where spruce is mainly grown for timber.

Some measures with potential repercussions on BS were not explored in this study. Diversionary feeding can lure red deer from sensitive stands (Arnold et al. 2018) and reduce $\mathrm{BS}$, but can also have dramatic consequences if mistakes are made, such as interruption in provisioning or provisioning of unsuitable food items (de Crombrugghe and Louis 1981). Diversionary feeding can also cause social stress inside herds due to competition for access to the feeding station, which can induce BS behavior (de Crombrugghe 1965; de Crombrugghe and Louis 1981). Selective branch pruning on a limited number of trees associated with individual protection means, such as net or bark scarification, can reduce BS probability up to $80 \%$ (Ueckermann et al. 1988). Such protection means could thus be an efficient way to combine high timber production services without having to maintain deer populations at low levels. The cost-effectiveness of these methods should be estimated in the current economic conditions.

Acknowledgments We are grateful to the officers of the Forest and Nature Department (DNF) for carrying out this considerable field survey and the contributors of the ACCRVF program. We particularly acknowledge Thibault Gheysen, Gauthier Ligot, Hugues Claessens (ULiege) and René Dahmen (DNF) for their valuable advice. We thank Fabian Petit (Hunting and Fishing Direction) for his support in the use of BS database. We are also grateful to Hugues Lecomte and Sébastien Bauwens (IPRFW), and Alain Servais (Comptoir Forestier) for access to valuable data. We also thank the E-OBS dataset from the EU-FP6 project ENSEMBLES (https://ensembles-eu.metoffice.com), the data providers in the ECA\&D project (https://www.ecad.eu), and the contributors to MODIS (terra and aqua) and OpenStreetMap Foundation.

Funding The study was financed by the public service of Wallonia (SPW) under the funding: "Accord-cadre de recherches et vulgarisation forestières" (ACCRVF 2014-2019). 


\section{Compliance with ethical standards}

Conflict of interest The authors declare that they have no conflict of interest.

\section{References}

Akashi N, Terazawa K (2005) Bark stripping damage to conifer plantations in relation to the abundance of sika deer in Hokkaido, Japan. For Ecol Manag 208:77-83. https://doi.org/10.1016/j.forec o.2004.10.073

Alderweireld M, Burnay F, Pitchugin M, Lecomte H (2015) Inventaire forestier wallon : résultats 1994-2012. SPW DGO DNF Direction des Ressources forestières, Jambes

Allen AM, Månsson J, Jarnemo A, Bunnefeld N (2014) The impacts of landscape structure on the winter movements and habitat selection of female red deer. Eur J Wildl Res 60:411-421. https://doi. org/10.1007/s10344-014-0797-0

Ando M, Yokota H-O, Shibata E (2003) Bark stripping preference of sika deer, Cervus nippon, in terms of bark chemical contents. For Ecol Manag 177:323-331

Apollonio M, Andersen R, Rory P (2010) European Ungulates and their Management in the 21st Century. Cambridge University Press, Cambridge

Arnold JM, Gerhardt P, Steyaert SMJG et al (2018) Diversionary feeding can reduce red deer habitat selection pressure on vulnerable forest stands, but is not a panacea for red deer damage. For Ecol Manag 407:166-173. https://doi.org/10.1016/j.forec o.2017.10.050

Baders E, Donis J, Snepsts G et al (2017) Pruning effect on Norway spruce (Picea abies (L.) Karst.) growth and quality. For Stud 66:33-48. https://doi.org/10.1515/fsmu-2017-0005

Bertouille S, Duran V, Fichefet V et al (2015) Rapport Cerf 20142015. SPW/DGO/DEMNA et DNF, Gembloux

Bertouille SB, de Crombrugghe SA (2002) Fertiliy of red deer in relation to area, age, body mass, and mandible length. Z Für Jagdwiss 48:87-98

Bolyn C, Michez A, Gaucher P et al (2018) Forest mapping and species composition using supervised. Biotechnol Agron Soc Env 22(3): 172-187

Borkowski J, Ukalski K (2012) Bark stripping by red deer in a postdisturbance area: The importance of security cover. For Ecol Manag 263:17-23. https://doi.org/10.1016/j.foreco.2011.09.029

Burnevča N, Jansons Ā, Zaḷuma A et al (2016) Fungi inhabiting bark stripping wounds made by large game on stems of $<\mathrm{i}>$ picea abies $<\mathrm{i} />$ (L.) karst. in latvia. Balt For 22:2-7

Caudullo G, Tinner W, de Rigo D (2016) Picea abies in Europe: distribution, habitat, usage and threats. In: San-Miguel-Ayanz J, de Rigo D, Caudullo G, Houston Durrant T, Mauri A (eds) European Atlas of Forest Tree Species. Publication Office of the European Union, Luxembourg, pp 114-116

Čermák P, Strejček M (2007) Stem decay by Stereum sanguinolentum after red deer damage in the Českomoravská vrchovina Highlands. J For Sci 53:567-572

Čermák P, Glogar J, Jankovskỳ L (2004) Damage by deer barking and browsing and subsequent rots in Norway spruce stands of Forest Range Mořkov, Forest District Frenštát p. R. (the Beskids Protected Landscape Area). J For Sci 50:24-30

Claessens H (2017) Les habitats forestiers. In: Blerot P, Heyninck C (eds) Le grand livre de la forêt. Forêt. Nature, Marche-enFamenne, pp 131-137
Colson V, Garcia S, Rondeux J, Lejeune P (2010) Map and determinants of woodlands visiting in Wallonia. Urban For Urban Green 9:83-91. https://doi.org/10.1016/j.ufug.2009.04.002

Conrad O, Bechtel B, Bock M, Dietrich H, Fischer E, Gerlitz L, Wehberg J, Wichmann V, Böhner J (2015) System for automated geoscientific analyses (SAGA) v. 2.1.4. Geosci. Model Dev. 8:1991-2007. https://doi.org/10.5194/gmd-8-1991-2015

Cukor J, Vacek Z, Linda R et al (2019) Effects of bark stripping on timber production and structure of norway spruce forests in relation to climatic factors. Forests 10:320. https://doi.org/10.3390/ f10040320

de Crombrugghe SA (1965) Beziehungen zwischen dem Umfang der Rotwildschäle in Buchenbeständen und den Niederschlägen. Z Für Jagdwiss 11:184-191

de Crombrugghe SA, Louis C (1981) Affouragement hivernal et écorcement chez le cerf (Cervus elaphus L.). Bull Société R For Belg 88:1-20

Delvaux J, Galoux A (1962) Les territoires écologiques du Sud-Est belge. Travaux hors-série. Bruxelles: ULB, Centre d'Écologie générale 2:311

Drimaj J, Kamler J, Mikulka O, Plhal R (2018) Bak stripping by red deer : the possible effect of recreational use of the landscape. Czech Republic, Krtiny, pp 69-72

EUFORGEN (2013) Distribution map of norway spruce (Picea abies) FAO. (2020) Forestry Production and Trade. License: CC BY-NC-SA 3.0 IGO. Extracted from: https://www.fao.org/faostat/. Date of Access: $14-05-2020$

Fehér Á, Szemethy L, Katona K (2016) Selective debarking by ungulates in temperate deciduous forests: preference towards tree species and stem girth. Eur J For Res 135:1131-1143. https://doi. org/10.1007/s10342-016-1000-9

Garel M, Bonenfant C, Hamann J-L et al (2010) Are abundance indices derived from spotlight counts reliable to monitor red deer Cervus elaphus populations? Wildl Biol 16:77-84. https://doi. org/10.2981/09-022

Gheysen T, Brostaux Y, Hébert J et al (2011) A regional inventory and monitoring setup to evaluate bark peeling damage by red deer (Cervus elaphus) in coniferous plantations in Southern Belgium. Environ Monit Assess 181:335-345. https://doi.org/10.1007/ s10661-010-1832-6

Gill RMA (1992) A review of damage by mammals in north temperate forests: 1. Deer Forestry 65:145-169

Hall DK, Riggs GA (2015) MODIS/Terra snow cover monthly L3 global 0.05Deg CMG, version 6. Years 2003 to 2017. Boulder, Colorado USA. NASA national snow and ice data center distributed active archive center. https://doi.org/10.5067/MODIS/ MOD10CM.006. Accessed on 3 Oct 2018

Hall DK, Riggs GA (2016) MODIS/Aqua snow cover monthly L3 global 0.05Deg CMG, version 6. Years 2003 to 2017. Boulder, Colorado USA. NASA national snow and ice data center distributed active archive center. https://doi.org/10.5067/MODIS/ MYD10CM.006. Accessed on 3 Oct 2018

Hébert J, Herman M, Jourez B (2002) Sylviculture et qualité du bois de l'épicéa en région wallonne. Forêt Wallonne, Jacques Hébert Belgique

Heyninck C (2014) Pertes en volume et en valeur d'épicéas adultes touchés par des dégâts de cervidés. For Wallonne 132:24-30

Honda T, Ueda H, Takiguchi K (2008) Risk factors affecting the probability of damage by sika deer in plantation forests in Yamanashi Prefecture, Japan. Landsc Ecol Eng 4:97-102. https://doi. org/10.1007/s11355-008-0047-2

Jarnemo A, Minderman J, Bunnefeld N et al (2014) Managing landscapes for multiple objectives: alternative forage can reduce the conflict between deer and forestry. Ecosphere 5:97. https://doi. org/10.1890/ES14-00106.1 
Jerina K (2012) Roads and supplemental feeding affect home-range size of Slovenian red deer more than natural factors. J Mammal 93:1139-1148. https://doi.org/10.1644/11-MAMM-A-136.1

Jerina K, Dajčman M, Adamič M (2008) Red deer (Cervus elaphus) bark stripping on spruce with regard to spatial distribution of supplemental feeding places. Zb Gozdarstva Lesar 86:33-43

Jönsson KI (1997) Capital and income breeding as alternative tactics of resource use in reproduction. Oikos 78:57-66. https://doi. org/10.2307/3545800

Kiffner C, Rossiger E, Trisl O et al (2008) Probability of recent bark stripping damage by red deer (Cervus elaphus) on Norway spruce (Picea abies) in a low mountain range in Germany-a preliminary analysis. Silva Fenn 42:125

Legrain X, Demarcin P, Colinet G, Bock L (2011) Cartographie des sols en Belgique : aperçu historique et présentation des travaux actuels de valorisationet de révision de la Carte Numérique des Sols de Wallonie. Biotechnol Agron Soc Environ 15:647-656

Li S, Colson V, Lejeune P, Vanwambeke SO (2016) On the distance travelled for woodland leisure via different transport modes in Wallonia, south Belgium. Urban For Urban Green 15:123-132. https://doi.org/10.1016/j.ufug.2015.12.007

Licoppe A, Lievens J (2010) Utilisation de la plaine agricole par le Cerf élaphe et effets sur les résultats de comptages aux phares: cas des prairies de la Vesdre en Hertogenwald (B). Colloque national d'écologie scientifique, Montpellier. -y-cologie-du-dy-placement. pdf

Licoppe AM (2006) The diurnal habitat used by red deer (Cervus elaphus L.) in the Haute Ardenne. Eur J Wildl Res 52:164-170. https ://doi.org/10.1007/s10344-006-0027-5

Licoppe AM, De Crombrugghe SA (2003) Assessment of spring habitat selection of red deer (Cervus elaphus L.) based on census data. Z Für Jagdwiss 49:1-13

Ligot G, Gheysen T, Lehaire F et al (2013) Modeling recent bark stripping by red deer (Cervus elaphus) in South Belgium coniferous stands. Ann For Sci 70:309-318. https://doi.org/10.1007/s1359 5-012-0253-9

Månsson J, Bunnefeld N, Andrén H, Ericsson G (2012) Spatial and temporal predictions of moose winter distribution. Oecologia 170:411-419. https://doi.org/10.1007/s00442-012-2305-0

Månsson J, Jarnemo A (2013) Bark-stripping on Norway spruce by red deer in Sweden: level of damage and relation to tree characteristics. Scand J For Res 28:117-125. https://doi.org/10.1080/02827 581.2012.701323

Milner JM, Bonenfant C, Mysterud A et al (2006) Temporal and spatial development of red deer harvesting in Europe: biological and cultural factors: Red deer harvesting in Europe. J Appl Ecol 43:721-734. https://doi.org/10.1111/j.1365-2664.2006.01183.x

Nopp-Mayr U, Reimoser F, Völk F (2011) Predisposition assessment of mountainous forests to bark peeling by red deer (Cervus elaphus 1.) as a strategy in preventive forest habitat management. Wildl Biol Pract 7:66-89

Pellerin M, Bonenfant C, Garel M et al (2014) Dynamique de la population de cerfs du domaine national de Chambord: analyse temporelle des indicateurs de changement écologique (ICE), Rapport d'expertise ONCFS. CNERAs cervidés-Sanglier faune montagne L'ONCFS LBBE-CNRS de l'université Lyon 1, Gières: 64

Perin J, Hébert J, Lejeune P, Claessens H (2016) De nouvelles normes sylvicoles pour les futaies pures équiennes d'épicéa et de douglas en appui à lagestion de la forêt publique en Wallonie. ForêtNature 139:58-67

Picard J, Oleffe P, Boisaubert B (1991) Inlfuence of oak mast on feeding behaviour of red deer (Cervus elaphus L). Ann For Sci 48:547-559
Rademacher P (2005) Contents of nutrient elements in tree components of economical important species in relation to their residual utilisation. Holz Als Roh- Werkst 63:285-296. https://doi. org/10.1007/s00107-004-0565-Z

Rivrud IM (2013) Space use, climate and selective harvesting. PhD University of Oslo, Norway

Saïd S, Malengreaux C, Lievens J, Licoppe A (2015) Response of Vaccinium myrtillus height to ungulates populations

Saint-Andrieux C, Bonenfant C, Toïgo C et al (2009) Factors Affecting Beech Fagus sylvatica Bark Stripping by Red Deer Cervus elaphus in a Mixed Forest. Wildl Biol 15:187-196. https://doi. org/10.2981/07-100

Spiecker H, Lindner M, Schuler JK (2019) Douglas-fir: an option for Europe. European Forest Institute, Joensuu

Timbal J, Bonneau M, Landmann J et al (2005) European non-boreal conifer forests. Coniferous forests. Elsevier, Amsterdam, pp $131-162$

Tricot Ch, Alexandred P, Berger A, et al (1994) Climat. In: Etat de l'Environnement Wallon 1994. Ministère de la Région Wallonne, Direction générale des Ressources naturelles et de l'Environnement, pp 125-247

Trisl O, Wode L, Aparslan A (1999) Sechs Jahre Schälschadeninventuren im Niedersächischen Forstamt Winnefeld. Forst Holz $54: 425-428$

Ueckermann E, Orthwein D, Ueckermann D (1988) Modification of mechanical-biological measures for the protection of the youngest spruce plantations I [Modifizierung der mechanisch-biologischen Maßnahmen zum Schälschutz der jüngsten Fichtenaltersstufe]. Z Für Jagdwiss 34:36-46

Ueda H, Takatsuki S, Takahashi Y (2002) Bark stripping of hinoki cypress by sika deer in relation to snow cover and food availability on Mt Takahara, central Japan. Ecol Res 17:545-551. https://doi. org/10.1046/j.1440-1703.2002.00513.x

Vasaitis R, Lygis V, Vasiliauskaite I, Vasiliauskas A (2012) Wound occlusion and decay in Picea abies stems. Eur J For Res 131:12111216. https://doi.org/10.1007/s10342-011-0592-3

Vasiliauskas R (2001) Damage to trees due to forestry operations and its pathological significance in temperate forests : a literature revieuw. Forestry 74:319-336

Vasiliauskas R, Stenlid J, Johansson M (1996) Fungi in bark peeling wounds of Picea abies in central Sweden. For Pathol 26:285-296

Verheyden H, Ballon P, Bernard V, Saint-Andrieux C (2006) Variations in bark-stripping by red deer Cervus elaphus across Europe. Mammal Rev 36:217-234

Völk FH (1999) Bark peeling frequency in the alpine provinces of Austria : Ther importance of forest strucrure and red deer management. Z Für Jagdwiss 45:1-16

Vospernik S (2006) Probability of bark stripping damage by red deer (Cervus elaphus) in Austria. Silva Fenn 40:589

Weiss AD (2000) Topographic position and landforms analysis. Poster. http://www.jennessent.com/downloads/tpi-poster-tnc_18x22.pdf

Wood SN (2011) Fast stable restricted maximum likelihood and marginal likelihood estimation of semiparametric generalized linear models. J R Stat Soc (B) 73(1):3-36. https://www.R-project.org/

Wood SN (2017) Generalized additive models: an introduction with R (2nd edn). Chapman and Hall/CRC

Zidar J (2011) Factors affecting bark-stripping by red deer (Cervus elaphus) the importance of landscape structure and forage availability. Swedish University of Agricultural Sciences, uppsala

Publisher's Note Springer Nature remains neutral with regard to jurisdictional claims in published maps and institutional affiliations. 